\title{
Metallothionein-I/II Knockout Mice Aggravate Mitochondrial Superoxide Production and Peroxiredoxin 3 Expression in Thyroid after Excessive Iodide Exposure
}

\author{
Na Zhang, ${ }^{1}$ Lingyan Wang, ${ }^{1}$ Qi Duan, ${ }^{1}$ Laixiang Lin, ${ }^{2}$ Mohamed Ahmed, \\ Tingting Wang, ${ }^{1}$ and Xiaomei Yao ${ }^{1}$ \\ ${ }^{1}$ Department of Pathophysiology, School of Basic Medical Sciences, Tianjin Medical University, Tianjin 300070, China \\ ${ }^{2}$ Key Lab of Hormones and Development of Ministry of Health, Institute of Endocrinology, Metabolic Disease Hospital, \\ Tianjin Medical University, Tianjin 300070, China
}

Correspondence should be addressed to Xiaomei Yao; jupx@163.com

Received 24 October 2014; Revised 13 January 2015; Accepted 11 February 2015

Academic Editor: Kaushik Biswas

Copyright $\odot 2015 \mathrm{Na}$ Zhang et al. This is an open access article distributed under the Creative Commons Attribution License, which permits unrestricted use, distribution, and reproduction in any medium, provided the original work is properly cited.

Purpose. We aim to figure out the effect of metallothioneins on iodide excess induced oxidative stress in the thyroid. Methods. Eight-week-old MT-I/II knockout (MT-I/II KO) mice and background-matched wild-type (WT) mice were used. Mitochondrial superoxide production and peroxiredoxin (Prx) 3 expression were measured. Results. In in vitro study, more significant increases in mitochondrial superoxide production and $\operatorname{Prx} 3$ expression were detected in the MT-I/II KO groups. In in vivo study, significantly higher concentrations of urinary iodine level were detected in MT-I/II KO mice in $100 \mathrm{HI}$ group. Compared to the NI group, there was no significant difference existing in serum thyroid hormones level in either groups $(P>0.05)$, while the mitochondrial superoxide production was significantly increased in $100 \mathrm{HI}$ groups with significantly increased LDH activity and decreased relative cell viability. Compared to WT mice, more significant changes were detected in MT-I/II KO mice in 100 HI groups. No significant differences were detected between the NI group and $10 \mathrm{HI}$ group in both the MT-I/II KO and WT mice groups $(P>0.05)$. Conclusions. Iodide excess in a thyroid without MT I/II protection may result in strong mitochondrial oxidative stress, which further leads to the damage of thyrocytes.

\section{Introduction}

Iodine is a fundamental constituent of thyroid hormones and has stimulatory effects on hydrogen peroxide $\left(\mathrm{H}_{2} \mathrm{O}_{2}\right)$ generation, which is involved in oxidative stress $[1,2]$. $150 \mu \mathrm{g}$ iodine is the daily requirement for thyroid hormone synthesis [3]. The International Council for the Control of Iodine Deficiency Disorders proposed that $150-299 \mu \mathrm{g} /$ day is adequate to cover the thyroid requirement, and the maximal allowable dietary dose of iodine is $1.0 \mathrm{mg} /$ day for children and $2.0 \mathrm{mg} /$ day for adults [4]. However, concentrations of iodine can be up to several hundredfold to thousandfold higher than the above amounts [5]. Intakes of up to $600 \mathrm{mg}$ per day in the European Union and $1100 \mathrm{mg}$ per day in the United States are declared as tolerable for adults [6]. Iodide excess has been demonstrated to be toxic to the thyroid [7-10] and may lead to hypothyroidism, hyperthyroidism, euthyroid goiter, or thyroid autoimmunity [3,11-13], with oxidative stress being one of the underlying mechanisms [14, 15]. Animal models with different iodine intake dietary were established in mice [16-18] and in rats $[19,20]$ to study the effects of excess iodine on the thyroid. Humans may get exposed to excess iodine through medications or diet. Substances involved in iodine excess include iodine-containing drugs, amiodarone being the prime offender. Approximately $9 \mathrm{mg}$ of iodine is released following a daily dose of $300 \mathrm{mg}$ amiodarone. Other substances include iodpovidone used for topical disinfection and seaweed. Seaweed preparations containing up to $2 \mathrm{mg}$ iodine per gram in protein-bound form and may cause dietary iodine intake to exceed $5000 \mathrm{mg}$ per day in populations with increased consumption [21, 22]. Contrast agents for conventional radiography or computer tomography may 
also lead to iodine excess. Radiologists use up to $100 \mathrm{~g}$ or more of iodine in complex organic molecules. Erythrosine, a food additive used to improve the colour of canned cherries or of candies, contains $57 \%$ iodine $[2,3]$. Although iodized salt programs have made great progress in the global effort to control iodine deficiency, they need to be carefully monitored to ensure adequate iodine intake while avoiding iodine excess [20].

The mitochondria contain specific receptors for thyroid hormones and are an important source of reactive oxygen species (ROS) [22]. Thyrocytes possess various enzymatic systems such as peroxidise (GPx), catalases, superoxide dismutases (SOD), and peroxiredoxins (Prxs) that contribute to limiting cellular injuries [23]. Peroxiredoxin $3(\operatorname{Prx} 3)$ is predominantly located in the mitochondria and is responsible for scavenging ROS. Prx 3 can be the target for up to $90 \%$ of hydrogen peroxide generated in the matrix [24]. Metallothioneins (MTs) have been demonstrated to have strong antioxidative activity in protecting cells from the damaging effects of ROS. They too are regarded as scavengers of ROS, including superoxide and hydroxyl radicals $[25,26]$.

In light of previous works documented on iodide induced oxidative stress and thyrotoxicity, we have demonstrated the time-course and concentration-response effects of early acute high concentrations of iodide exposure on mitochondrial superoxide generation. When endogenous antioxidant systems were overwhelmed by high concentrations of iodide induced ROS production, they began attacking proteins, lipid, and nucleic acids [15]. However the nature of iodide excess induced oxidative stress in thyroid with or without MT I/II remains to be determined.

By targeting mitochondrial superoxide production and Prx 3 protein expression, we aimed to figure out the effect of high concentrations of iodide on mitochondrial superoxide production and Prx 3 expression in the thyroids of metallothionein I/II knockout (MT-I/II KO) mice in vitro and in vivo. We propose that iodide excess in a thyroid without MT I/II protection may result in strong mitochondrial oxidative stress, which further leads to the damage of thyrocytes.

\section{Methods}

2.1. Animals and Thyroid Cell Suspension Preparation. Eightweek-old 129S7/SvEvBrd-Mt1 ${ }^{\text {tm1Bri }} \mathrm{Mt}^{\text {tm1Bri }} /$ (MT-I/II knockout, MT-I/II KO) mice (number 002211, Jackson Lab, Maine, USA) and background-matched wild-type (WT) mice were used. In the in vitro study, a thyroid cell suspension was prepared. A cell suspension $\left(5 \times 10^{4}\right.$ cells/well $)$ was incubated in medium RPMI-1640 with 10\% fetal bovine serum (FBS) at $37^{\circ} \mathrm{C}$ in an atmosphere comprising $5 \% \mathrm{CO}_{2}$ and $95 \%$ air and exposed to high concentrations of potassium iodide (KI) or $10^{-3} \mathrm{M} \mathrm{H}_{2} \mathrm{O}_{2}$ for 2 hours. In vivo, MT-I/II KO and WT mice were randomly divided into control groups (normal iodide intake, NI), 10 times iodide intake groups (10 HI), and 100 times iodide intake groups $(100 \mathrm{HI})$. NI groups received deionized water and a normal diet (daily iodide uptake is $1.5 \mu \mathrm{g} / \mathrm{d}$ ). In the $10 \mathrm{HI}$ and $100 \mathrm{HI}$ groups, $15 \mu \mathrm{g} / \mathrm{d}$ and $150 \mu \mathrm{g} / \mathrm{d}$ KI were added, respectively, to the deionized water for 14 days before sacrifice. Animal procedures were approved by the Institutional Animal Care and Use Committee of Tianjin Medical University and in accordance with the NIH Guide.

2.2. Reagents. MitoSOX Red (3,8-phenanthridinediamine, 5-(6'-triphenylphosphoniumhexyl)-5,6-dihydro-6-phenyl) was purchased from Invitrogen (Invitrogen Life Technologies, CA, USA). Anti-Peroxiredoxin 3 antibody was purchased from Abcam (Abcam, Cambridge, MA, USA). $\beta$-Actin Rabbit $\mathrm{mAb}$ was purchased from Cell Signaling (Cell Signaling Technology, Inc., MA, USA). 3-(4,5-Dimethylthiazol-2-yl)-2,5-diphenyl-tetrazolium bromide (MTT) and TSH were purchased from Sigma (Sigma-Aldrich, MO, USA). RPMI-1640 and FBS were purchased from GE Healthcare Life Sciences (Hyclone, UT, USA). All the other chemicals made in China were of analytical grade.

2.3. Cell Viability Assay. Cell viability was evaluated with the MTT assay. A cell suspension $\left(5 \times 10^{4}\right.$ cells/well) was incubated in medium RPMI-1640 with $10 \%$ fetal bovine serum $(\mathrm{FBS})$ at $37^{\circ} \mathrm{C}$ in an atmosphere comprising $5 \% \mathrm{CO}_{2}$ and $95 \%$ air and exposed to high concentrations of potassium iodide (KI) or $10^{-3} \mathrm{M} \mathrm{H}_{2} \mathrm{O}_{2}$ for 2 hours in order to get a final concentration of $10^{-4} \mathrm{M}, 10^{-3} \mathrm{M}$, and $10^{-2} \mathrm{M}$. The group without $\mathrm{KI}$ is the control group; the well with only medium in is regarded as blank group. Subsequently, $10 \mu \mathrm{L}$ of $3-$ (4,5-dimethylthiazol-2-yl)-2,5-diphenyltetrazolium bromide (MTT, $5 \mathrm{mg} / \mathrm{mL}$ ) was added in dark and incubated for $4 \mathrm{~h}$ and covered with aluminium foil. After incubation for 2 hours, the supernatant was removed, and $100 \mu \mathrm{L}$ of DMSO was added to each well to dissolve the formazan crystals formed and was then shaken for $10 \mathrm{~min}$. Absorbance was measured by a spectrophotometer at $490 \mathrm{~nm}$ (Wallac 1420 VICTOR3, PerkinElmer) $[33,34]$.

2.4. Lactate Dehydrogenase ( $\mathrm{LDH}$ ) Assay. $\mathrm{LDH}$ release in the supernatant following different treatments was measured using a cytotoxicity detection kit (LDH) (Nanjing Jiancheng Bioengineering Institute, Jiangsu, China). LDH is an oxidoreductase that catalyzes the interconversion of lactate and pyruvate. $\mathrm{LDH}$ is a stable cytosolic enzyme that upon membrane damage is released into cell culture media. The assay is based on the reduction of the 2-p-iodophenyl3-nitrophenyl tetrazolium chloride (tetrazolium INT) to a red formazan which is specifically detected by colorimetric $(450 \mathrm{~nm})$ assay.

2.5. Flow Cytometry. A mitochondrial superoxide indicator (MitoSOX Red, Invitrogen) was used to measure mitochondrial superoxide production by flow cytometry. In vivo, the thyroid cell suspension of MT-I/II KO and WT mice was prepared for (normal iodide intake, NI) 10 times iodide intake groups $(10 \mathrm{HI})$ and 100 times iodide intake groups $(100 \mathrm{HI})$. For the in vitro study, a thyroid cell suspension was prepared first. The thyroid cell suspension was exposed to high concentrations of potassium iodide (KI) $\left(10^{-4} \mathrm{M}\right.$, $10^{-3} \mathrm{M}$, and $10^{-2} \mathrm{M}$ ) or $10^{-3} \mathrm{M} \mathrm{H}_{2} \mathrm{O}_{2}$ for 2 hours. Subsequently, $5 \mu \mathrm{M}$ of MitoSOX was added and incubated for $10 \mathrm{~min}$ at $37^{\circ} \mathrm{C}$ in the dark. Then the cells were washed 
with Hank's solution and were suspended in Hank's solution with $1 \%$ BSA. The fluorescence intensity of MitoSOX was detected by a FACSCalibur (BD Bioscience, San Jose, CA), and the excitation/emission wavelength is $488 \mathrm{~nm} / 575 \mathrm{~nm}$. Collecting FL2 channel forward scattering (forward scatter, FSC) and lateral scattering (side scatter, SSC) data, 10000 cells were collected for each sample. The control group without MitoSOX was regarded as the blank zero group for standardization [35-38].

2.6. Western Blot Analysis. Whole cell proteins were assayed for protein concentration using the bicinchoninic acid (BCA) protein assay kit (Beyotime Institute of Biotechnology, Jiangsu, China). $50 \mu \mathrm{g}$ of protein was transferred to nitrocellulose membrane followed by SDS polyacrylamide gel electrophoresis. The nitrocellulose membrane was incubated overnight with primary antibodies: Anti-Peroxiredoxin 3 antibody (Abcam, Cambridge, MA, USA) and horseradish peroxidase (HRP) conjugated secondary antibody, developed by Immobilon Western Chemiluminescent HRP Substrate (Merck Millipore, MA, USA). To verify equal loading, $\beta$ actin $(1: 1000)$ (Cell Signaling Technology, Inc., MA, USA) was used as a loading control. Blots were scanned as grayscale images and quantitated using Image J software (NIH). All the blot intensities were normalized with that of loading control $\beta$-actin [39].

2.7. Determination of Urinary Iodine Concentrations and Serum Thyroid Hormones. Spot urine samples of mice were collected and urinary iodine concentrations were measured by As-Ce catalytic spectrophotometry in the Key Lab of Hormones and Development Ministry of Health, Institute of Endocrinology, Tianjin Medical University [40]. Blood was obtained 14 days after NI, $10 \mathrm{HI}$, or $100 \mathrm{HI}$ intake. Samples of blood were centrifuged for $10 \mathrm{~min}$; serum samples were obtained and stored at $-80^{\circ} \mathrm{C}$ for use. Serum concentrations of thyroxine $\left(\mathrm{T}_{4}\right)$, free thyroxine $\left(\mathrm{FT}_{4}\right)$, triiodothyronine $\left(\mathrm{T}_{3}\right)$, and free triiodothyronine $\left(\mathrm{FT}_{3}\right)$ were determined by using the Direct Chemiluminescence Technology Competitive Immunoassay Kits (Siemens Healthcare Diagnostic, Inc.).

2.8. Statistics. The data was represented as mean \pm SD. Based on the Kolmogorov-Smirnov (K-S) for normality test and Levene statistic for the test of homogeneity of variances. Urinary iodine concentrations were expressed as the median and determined with the nonparametric Kruskal-Wallis test; one-way ANOVA with the least significant difference (LSD) test was performed using SPSS 17.0 to determine the differences between the groups. A $P$ value of less than 0.05 was considered to be statistically significant.

\section{Results}

3.1. Effect of MT-I/II on High Concentrated Iodide Exposure Induced Mitochondrial Superoxide Production and Prx 3 Protein Expression In Vitro. To investigate the antioxidative role of MT-I/II in oxidative stress induced by high concentrations of iodide in the thyroid, thyroid cell suspensions were
TABLE 1: The median urinary iodine concentrations $(\mu \mathrm{g} / \mathrm{L})$ of WT mice and MT-I/II KO mice.

\begin{tabular}{lcc}
\hline Group & WT & MT-I/II KO \\
\hline NI & $320.29 \pm 112.16$ & $424.33 \pm 131.95$ \\
$10 \mathrm{HI}$ & $3592.92 \pm 519.98^{*}$ & $3949.24 \pm 647.93^{*}$ \\
$100 \mathrm{HI}$ & $30479.17 \pm 4128.94^{*}$ & $40666.35 \pm 3520.46^{* \#}$ \\
\hline
\end{tabular}

${ }^{*}$ Compared to the NI group $(P<0.05) ;{ }^{\#} \mathrm{WT}$ mice group compared to MTI/II KO mice group $(P<0.05) . N=10$ for each group.

prepared from the thyroid of MT-I/II KO mice and WT mice. The cells were then exposed to high concentrations of $\mathrm{KI}\left(10^{-4} \mathrm{M}, 10^{-3} \mathrm{M}\right.$, and $\left.10^{-2} \mathrm{M}\right)$ or $10^{-3} \mathrm{M} \mathrm{H}_{2} \mathrm{O}_{2}$ for 2 hours. Following $10^{-4} \mathrm{M}, 10^{-3} \mathrm{M}$, and $10^{-2} \mathrm{M}$ of KI or $10^{-3} \mathrm{M}$ $\mathrm{H}_{2} \mathrm{O}_{2}$ exposure, we showed a significant increase in mitochondrial superoxide production with increased MitoSOX Red fluorescence intensity $(P<0.05)$ (Figure $1(\mathrm{~d}))$ and an increase in LDH release $(P<0.05)$ (Figure $1(\mathrm{c})$ ) with a decrease in relative cell viability $(P<0.05)$ (Figure $1(\mathrm{a}))$ in the thyroid cell suspensions of both MT-I/II KO and WT mice groups. Compared to WT mice group, a more significant increase of mitochondrial superoxide production, increase in $\mathrm{LDH}$ release, and decrease in a relative cell viability can be detected in MT-I/II KO mice group $(P<0.05)$ (Figures 1(d), 1(c), and 1(a)). Compared to control group, the Prx 3 protein expressions were significantly increased in $10^{-2} \mathrm{M} \mathrm{KI}$ or $10^{-3} \mathrm{M} \mathrm{H}_{2} \mathrm{O}_{2}$ exposure group in both MT-I/II KO and WT mice groups $(P<0.05)$. Compared to WT mice group, there was a significant increase of Prx 3 protein expression in the thyroid cell suspensions of MT-I/II KO mice with the increase of KI concentration $(P<0.05)$ (Figure $1(b))$.

3.2. Urinary Iodine Concentrations In Vivo. In order to verify the model of iodine excess in vivo, urinary iodine concentrations were detected after the MT-I/II KO mice and WT mice had NI, $10 \mathrm{HI}$, and $100 \mathrm{HI}$ for 14 days. The median urinary iodine concentrations in NI, $10 \mathrm{HI}$, and $100 \mathrm{HI}$ were shown in Table 1 . The high iodide intake of $10 \mathrm{HI}$ group and $100 \mathrm{HI}$ group in both MT-I/II KO mice and WT mice resulted in significant increases in urinary iodine concentration when compared to theNI group $(P<0.05)$. The urinary iodine concentrations were increased as the iodine supply increased to $10 \mathrm{HI}, 100 \mathrm{HI}$ in both WT and MT-I/II KO mice. Moreover, compared to $10 \mathrm{HI}$ group, the extent of increase in urinary iodine concentration in $100 \mathrm{HI}$ was significantly higher $(P<$ 0.05). Compared to WT mice, MT -I/II KO mice had a more prominent increase of urinary iodine concentration in $100 \mathrm{HI}$ group $(P<0.05)$.

3.3. Changes of Serum Thyroid Hormones Level in WT and MT-I/II KO Mice following NI, $10 \mathrm{HI}$, or $100 \mathrm{HI}$ Intake for 14 Days. We demonstrated that, compared to the NI group, there was no significant difference existing in serum thyroid hormones level $\left(\mathrm{T}_{3}, \mathrm{~T}_{4}, \mathrm{FT}_{3}\right.$, and $\left.\mathrm{FT}_{4}\right)$ in either $10 \mathrm{HI}$ group or $100 \mathrm{HI}$ group in both WT mice and MT-I/II KO mice $(P>0.05)$. However, compared to WT mice, there was a significant difference in serum thyroid hormones level 


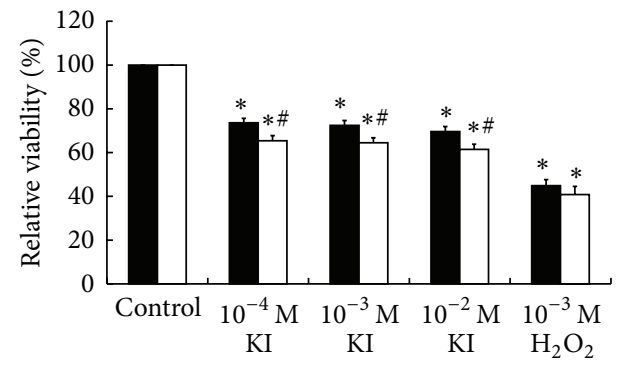

WT mice

MT-I/II KO mice

(a)

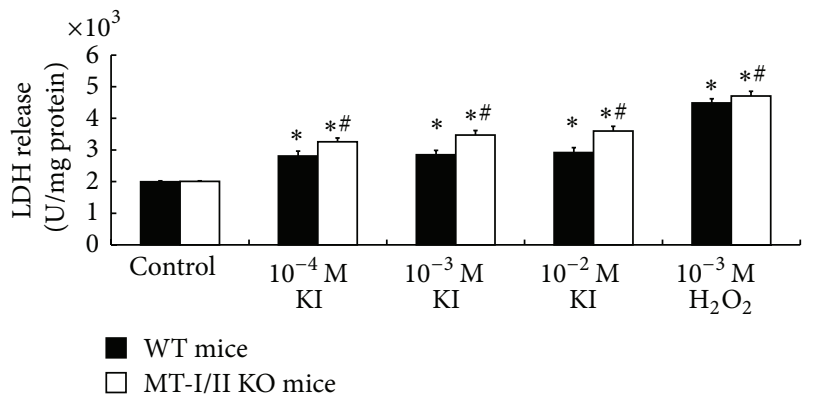

(c)

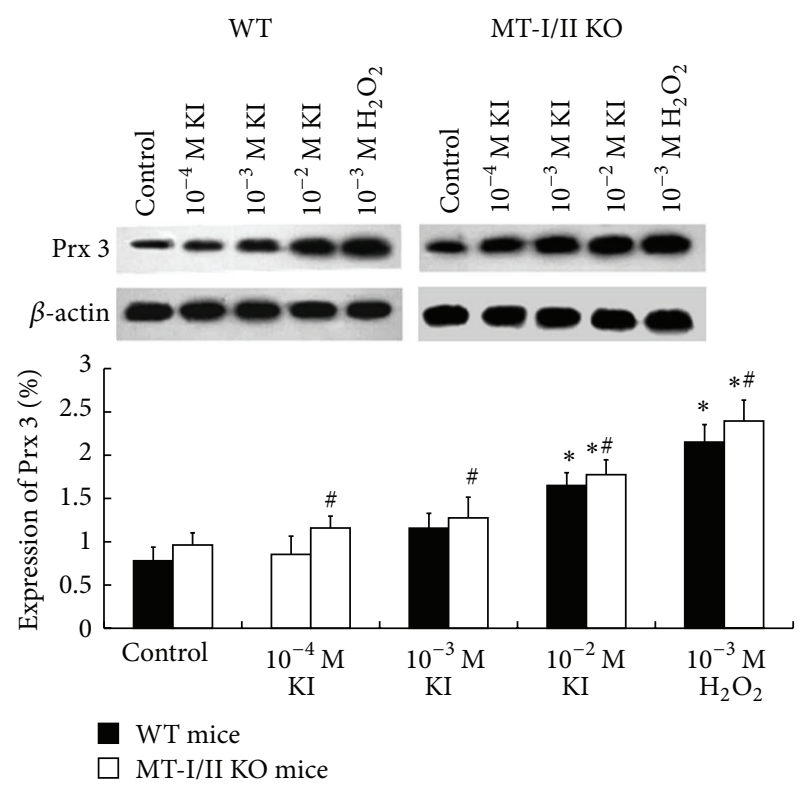

(b)
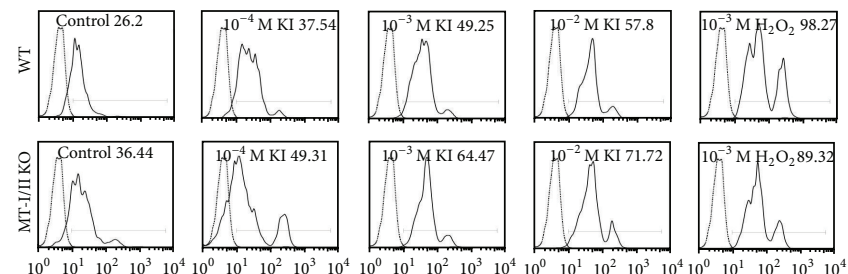

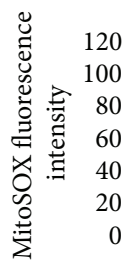

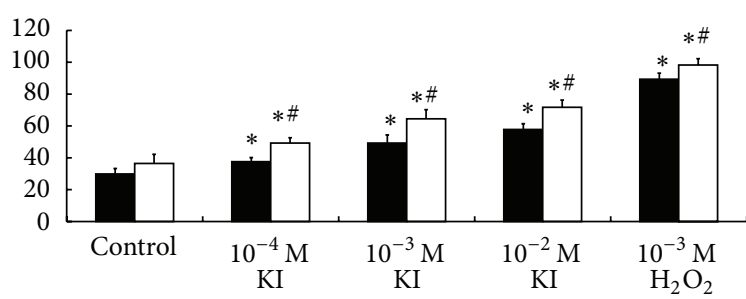

- WT mice

$\square$ MT-I/II KO mice

(d)

FIGURE 1: Oxidative and antioxidative effect of high concentrations of KI on the mitochondria of thyrocytes in MT-I/II KO mice and WT mice. (a) Decreased relative viability induced by high concentrations of $\mathrm{KI}\left(10^{-4} \mathrm{M}, 10^{-3} \mathrm{M}\right.$, and $\left.10^{-2} \mathrm{M}\right)$ or $10^{-3} \mathrm{M} \mathrm{H}_{2} \mathrm{O}_{2}$ in the thyroid cells of MT-I/II KO mice by MTT assay $(N=8)$. (b) Representative western blot of Prx $3(27 \mathrm{kDa}), \beta$-actin $(45 \mathrm{kDa})$ was used as a loading control. Densitometric analysis showed a significant increase $\left({ }^{*} \mathrm{P}<0.05\right)$ in $\operatorname{Prx} 3$ expression compared to untreated control in the thyroid cells of either WT or MT-I/II KO mice. (c) Increased LDH release following $2 \mathrm{~h}$ of high concentration of $\mathrm{KI}_{\text {or }} \mathrm{H}_{2} \mathrm{O}_{2}$ exposure in the thyroid cells of MT-I/II KO mice $(N=8)$. (d) High concentration of $\mathrm{KI}$ or $\mathrm{H}_{2} \mathrm{O}_{2}$ induced increased mitochondrial superoxide production in the thyroid cells of WT and MT-I/II KO mice. Histogram analysis was performed on the mean fluorescence intensity of MitoSOX Red as measured by flow cytometry. Experiments were repeated 3 times with similar results. Data are represented as mean \pm SD. One-way ANOVA with the LSD test was used. ${ }^{*} P<0.05$ compared with the control group of WT or MT-I/II KO mice, respectively; ${ }^{\#} P<0.05$ WT mice versus MT-I/II KO mice under the same treatment.

$\left(\mathrm{FT}_{4}\right)$ in $100 \mathrm{HI}$ group in MT-I/II KO mice $(P<0.05)$ (Table 2).

\subsection{High Iodide Intake Induced Increased Mitochondrial} Superoxide Production and Peroxiredoxin 3 Expression in Thyroid In Vivo. To clarify the effect of iodide excess on mitochondrial superoxide production and Prx 3 protein expression in thyroid of MT-I/II KO mice in vivo, mice were divided into normal iodide intake (NI), 10 times iodide intake $(10 \mathrm{HI})$, and 100 times iodide intake $(100 \mathrm{HI})$ groups. Compared to the NI group, the mitochondrial superoxide production measured by flow cytometry, Prx 3 protein expression detected by western blot analysis, and LDH release in $100 \mathrm{HI}$ group were significantly increased in both MT-I/II 
TABLE 2: Changes of serum thyroid hormones level (nmol/L) in WT and MT-I/II KO mice following NI, $10 \mathrm{HI}$, or $100 \mathrm{HI}$ intake for 14 days.

\begin{tabular}{lcccc}
\hline Group & $\mathrm{T}_{3}$ & $\mathrm{~T}_{4}$ & $\mathrm{FT}_{3}$ & \\
\hline WT & & & & $\mathrm{FT}_{4}$ \\
NI & $0.72 \pm 0.13$ & $26.08 \pm 14.21$ & $4.80 \pm 0.42$ & $28.56 \pm 4.51$ \\
$10 \mathrm{HI}$ & $0.53 \pm 0.09$ & $33.50 \pm 4.45$ & $4.26 \pm 0.41$ & $31.42 \pm 0.95$ \\
$100 \mathrm{HI}$ & $0.71 \pm 0.13$ & $34.70 \pm 13.24$ & $4.61 \pm 0.25$ & $33.20 \pm 4.55$ \\
MT-I/II KO & & & & \\
NI & $0.58 \pm 0.15$ & $20.05 \pm 4.68$ & $4.04 \pm 0.77$ & $25.69 \pm 0.97$ \\
$10 \mathrm{HI}$ & $0.69 \pm 0.13$ & $22.53 \pm 7.79$ & $4.78 \pm 0.05$ & $27.22 \pm 1.03$ \\
$100 \mathrm{HI}$ & $0.80 \pm 0.22$ & $17.73 \pm 6.76$ & $5.01 \pm 0.73$ & $23.99 \pm 1.92^{*}$ \\
\hline
\end{tabular}

${ }^{*}$ In $100 \mathrm{HI}$ group, compared to WT mice, there was a significant difference in serum thyroid hormones level $\left(\mathrm{FT}_{4}\right)$ in MT-I/II KO mice $(P<0.05) . N=8$ for each group.

KO and WT groups $(P<0.05)$. Compared to WT group, more significant increases in the mitochondrial superoxide production, Prx 3 protein expression, and $\mathrm{LDH}$ release were detected in MT-I/II KO group $(P<0.05)$. There were no significant differences between the NI group and $10 \mathrm{HI}$ group in both MT-I/II KO and WT mice $(P>0.05)$. Compared with the NI group, relative cell viability of $100 \mathrm{HI}$ group decreased in both the MT-I/II KO and WT mice groups $(P<0.05)$. Compared to the WT group, a more significant decrease in relative cell viability was detected in MT-I/II KO group $(P<$ $0.05)$. No significant difference of relative cell viability was detected between NI group and $10 \mathrm{HI}$ group in both MT-I/II $\mathrm{KO}$ and WT mice groups $(P>0.05)$ (Figure 2).

\section{Discussion}

Iodide excess has been recognized as a risk factor for the development of thyroid disease in humans and animals [713]. One of the underlying mechanisms is that the increased oxidative stress induced by iodide excess cannot be balanced by endogenous antioxidant systems $[14,15]$. In the present study, we focused the research on excessive iodide induced mitochondrial superoxide production and Prx 3 expression in the thyroid with or without MT I/II in vitro and in vivo.

In a previous study [15], we showed that the concentration response of KI induced a decrease in cell viability in FRTL cells by MTT assay; compared to the control group, the relative viability of $10^{-5} \mathrm{M}, 10^{-4} \mathrm{M}, 10^{-3} \mathrm{M}$, and $10^{-2} \mathrm{M} \mathrm{KI}$ exposure groups was significantly decreased at $24 \mathrm{~h}$. However, no significant decrease in the $10^{-6} \mathrm{M}$ or $10^{-7} \mathrm{M}$ KI exposure groups was observed. A strong stimulatory effect of iodide was detected in $10^{-4} \mathrm{M} \mathrm{KI}$ and in $10^{-3} \mathrm{M}$ KI exposure groups at the $2 \mathrm{~h}$ time point [15]. Iodide had a stimulatory effect on $\mathrm{H}_{2} \mathrm{O}_{2}$ generation and, when increased, $\mathrm{H}_{2} \mathrm{O}_{2}$ is considered as a limiting step in the biosynthesis of thyroid hormones [1]. The normal relative cell viability in the $10^{-6} \mathrm{M}$ or $10^{-7} \mathrm{M}$ KI exposure groups can be explained by the physiological effect of iodide, which is necessary for the biosynthesis of thyroid hormones [15]. We used KI concentrations of $10^{-4} \mathrm{M}$ and above in the in vitro study and NI, $10 \mathrm{HI}$, and $100 \mathrm{HI}$ in the in vivo study. In bovine thyroid slices, the maximal stimulation effect on $\mathrm{H}_{2} \mathrm{O}_{2}$ generation was obtained after $2 \mathrm{~h}$ of preincubation with $10^{-4} \mathrm{M} \mathrm{KI}$ [1]. It was reported that, in vitro, the acute toxic effects of high iodide doses in human thyroid follicles significantly increased the percentage of necrotic cells in $10^{-5} \mathrm{M}$ and doubled with $10^{-3} \mathrm{M}$ as compared to values measured at $10^{-7} \mathrm{M}[10]$. Iodide concentrations of $10^{-4} \mathrm{M}$ or greater may inhibit the iodothyronine synthesis and thyroid hormone secretion [41]. The concentrations from $10^{-5}$ to $10^{-3} \mathrm{M}$ were from 100 to 10,000 times higher than the normal iodine plasma levels estimated to be $10^{-7} \mathrm{M}$, in euthyroid human beings [42].

In the present study, we detected that, in $100 \mathrm{HI}$ intake group, there is a significant change of $\mathrm{FT}_{4}$ in $\mathrm{MT}-\mathrm{I} / \mathrm{II} \mathrm{KO}$ mice compared to WT mice; however, the values remain within the normal range in thyroid function. The NI and $10 \mathrm{HI}$ groups in both WT and MT-I/II KO mice were under normal conditions and the thyroid function was not affected. Iodine is essential for the synthesis of the thyroid hormones. In most individuals, the decreased production of thyroid hormones is only transient and resumes after adaptation to the acute Wolff-Chaikoff effect [43]. A detailed analysis reveals a persistent drop of serum $\mathrm{T}_{4}$ and $\mathrm{T}_{3}$ of $25 \%$ and $15 \%$, respectively, and a rise of TSH of $2 \mathrm{mU} / \mathrm{L}$. Although no clinical signs of thyroid dysfunction or goiter were found, sonographic thyroid volume is slightly increased $[2,29-32,44,45]$. Exposure to high concentrations of iodine may decrease the release of thyroid hormone shown by the increase in the serum level of TSH [27, 28, 46] (Table 3).

Thyroid toxicity of iodide excess has been demonstrated in vitro and in animals fed with an iodide-rich diet [42]. We showed that high concentrated iodide induced cytotoxicity in thyrocytes, significantly increasing mitochondrial superoxide anion production in the thyroid in high concentrated iodide exposure in vitro and in $100 \mathrm{HI}$ diet in vivo, in both MT-I/II KO and WT mice, which leads to the decreased relative cell viability in the thyroid. It is suggested that oxidative stress is the underlying mechanism in iodide excess induced apoptosis in thyroid cells [42]. Consistent with previous reports $[42,47-49]$, we showed that there is a strong increase of superoxide anion production in FRTL cells following high concentrations of iodide exposure [15]. Serrano-Nascimento et al. also observed that iodide excess increased ROS production in thyrocytes and mitochondria were the source of superoxide anion production [50]. The oxidative attack can be explained by the oxidative effect 


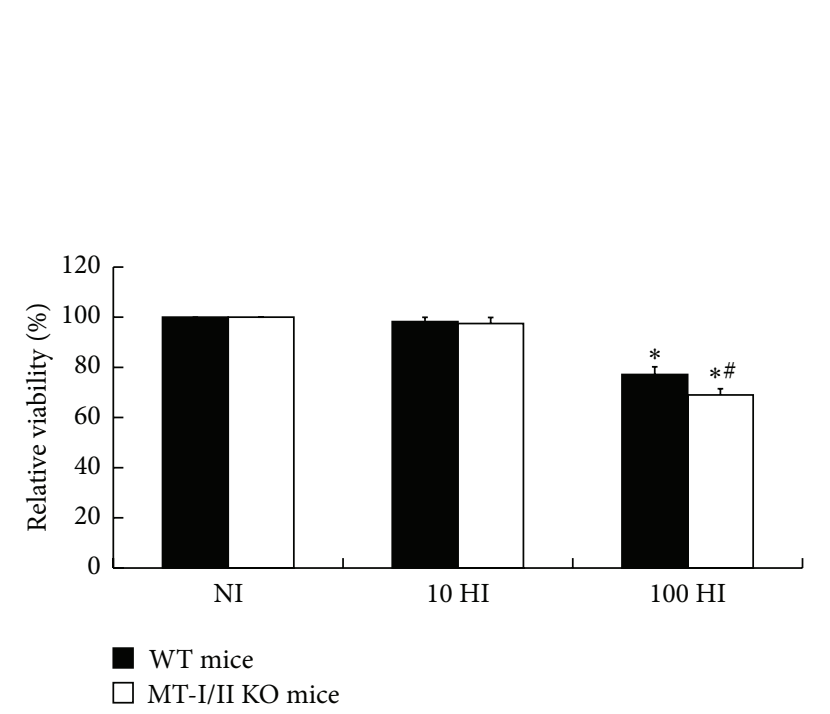

(a)

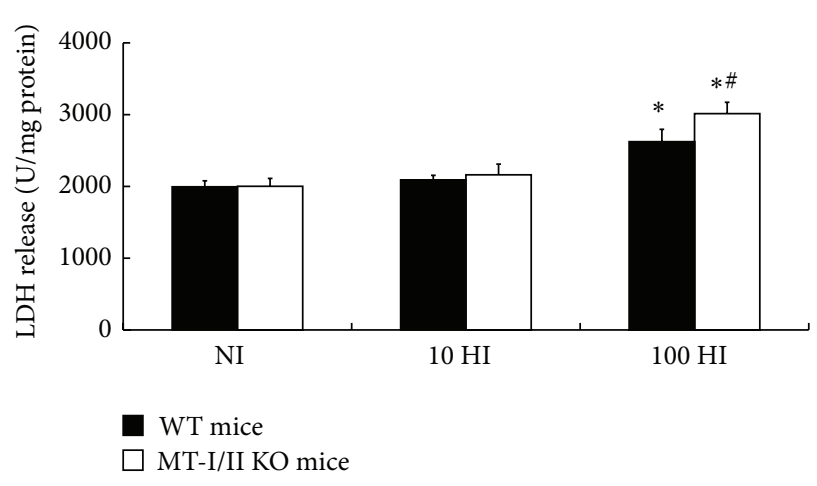

(c)

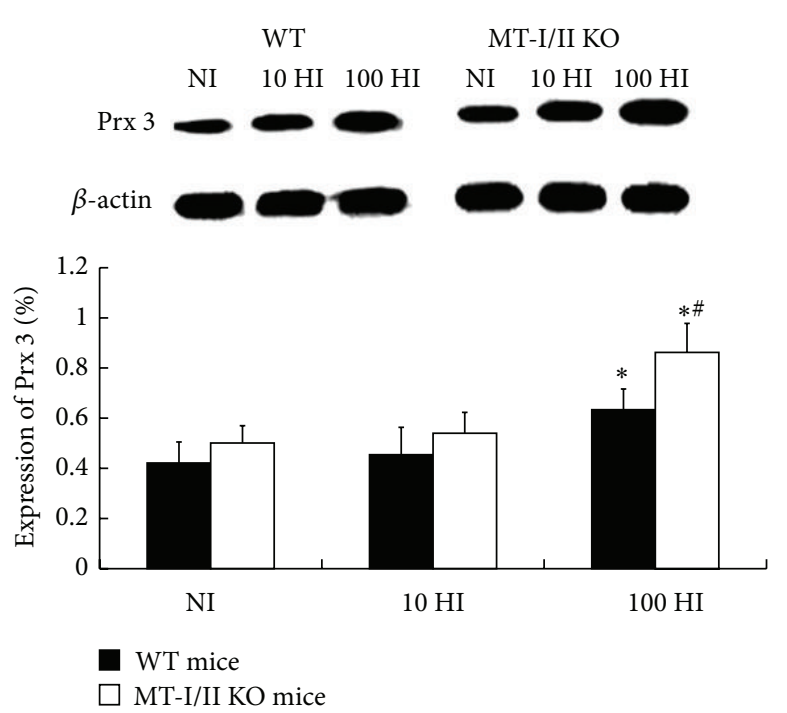

(b)
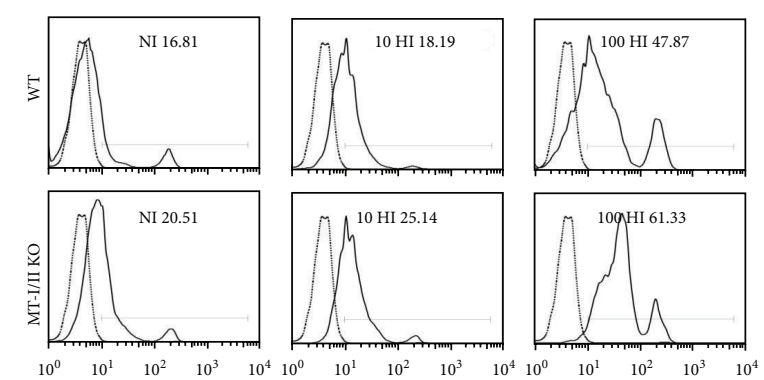

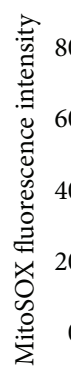
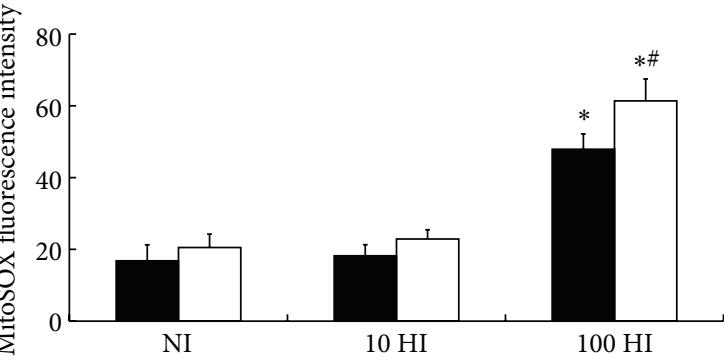

WT mice

$\square$ MT-I/II KO mice

(d)

FIGURE 2: Mitochondrial superoxide production, Prx 3 protein expression, and LDH release and relative viability in the thyroid of WT and MT-I/II knockout mice following NI, $10 \mathrm{HI}$, or $100 \mathrm{HI}$ diet for 14 days. (a) $100 \mathrm{HI}$ intake decreased the relative viability in thyroid of MT-I/II KO and WT mice. (b) Representative western blot of $\operatorname{Prx} 3(27 \mathrm{kDa}), \beta$-actin $(45 \mathrm{kDa})$ was used as a loading control. Densitometric analysis showed a significant increase in Prx 3 expression in $100 \mathrm{HI}$ group in the thyroid of either WT or MT-I/II KO mice, especially in MT-I/II KO mice. (c) $100 \mathrm{HI}$ increased the LDH release in the thyroid of MT-I/II KO and WT mice. (d) $100 \mathrm{HI}$ intake increased the mitochondrial superoxide production in thyroid of WT and MT-I/II KO mice. Histogram analysis was performed on the mean fluorescence intensity of MitoSOX Red as measured by flow cytometry. Experiments were repeated 3 times with similar results. Data are represented as mean \pm SD ( $N=10$ /group). One-way ANOVA with the LSD test was used. ${ }^{*} P<0.05$ compared with the control group of WT or MT-I/II KO mice, respectively; ${ }^{\#} P<0.05$ WT mice compared with the MT-I/II KO mice under the same treatment.

of $\mathrm{HI}$ diet on the thyroid gland. ROS include free radicals, such as the superoxide anion, hydroxyl radicals, and the nonradical hydrogen peroxide. Whether cells die from oxidative stress induced apoptosis depends on the balance between the generation of oxidant species and the antioxidant system.
In addition, we demonstrated that no significant difference was detected between NI group and $10 \mathrm{HI}$ group in both MT-I/II KO and WT mice groups. This can be explained by the fact that, under basal conditions, thyroid epithelial cells produce moderate amounts of ROS that are physiologically required for thyroid hormone synthesis [14]. Physiologically, 
TABLE 3: Documented literatures of iodide intake and changes of serum thyroxine $\left(\mathrm{T}_{4}\right)$ and triiodothyronine $\left(\mathrm{T}_{3}\right)$ concentrations.

\begin{tabular}{|c|c|c|c|c|}
\hline Dosage of daily iodine intake & Time & Subject & Changes of serum $\mathrm{T}_{4}, \mathrm{~T}_{3}$ concentrations & Reference \\
\hline 250 or $500 \mu \mathrm{g}$ & 14 days & Normal volunteers & No change & {$[27]$} \\
\hline $1500 \mu \mathrm{g}$ & 14 days & Normal volunteers & $\mathrm{T}_{4}, \mathrm{~T}_{3} \downarrow \mathrm{TSH} \uparrow$ & {$[27]$} \\
\hline 50 or $250 \mathrm{mg}$ & 13 days & Normal subjects & $\begin{array}{c}\mathrm{T}_{4}, \mathrm{~T}_{3} \downarrow \mathrm{TSH} \uparrow \\
\text { (within normal range) } \\
\end{array}$ & {$[28]$} \\
\hline $27 \mathrm{mg}$ & 4 weeks & Normal volunteers & $\begin{array}{c}\mathrm{T}_{4} \text { within the normal range except for } \\
\text { two subjects TSH } \uparrow \\
\end{array}$ & [29] \\
\hline $\begin{array}{l}\text { Single doses of } 10,30,50 \text {, and } 100 \mathrm{mg} \text { and } \\
\text { then daily doses of } 10,15,30,50 \text {, or } 100 \mathrm{mg}\end{array}$ & 12 days & Euthyroid volunteers & $\mathrm{T}_{3}, \mathrm{~T}_{4} \downarrow \mathrm{TSH} \uparrow$ & {$[30]$} \\
\hline $190 \mathrm{mg}$ & 10 days & Euthyroid volunteers & $\mathrm{T}_{3}, \mathrm{~T}_{4} \downarrow \mathrm{TSH} \uparrow$ & {$[31]$} \\
\hline $114 \mathrm{mg}$ & 3-7 weeks & Normal controls & $\mathrm{T}_{3}, \mathrm{~T}_{4} \downarrow \mathrm{TSH} \uparrow$ & {$[32]$} \\
\hline $114 \mathrm{mg}$ & $3-7$ weeks & Thyrotoxic patients & $\begin{array}{c}\mathrm{T}_{4}, \mathrm{~T}_{3} \uparrow \text { in some cases; } \\
\text { other patients remained } \\
\text { euthyroid even after } 6 \text { weeks }\end{array}$ & {$[32]$} \\
\hline $114 \mathrm{mg}$ & 2 weeks & $\begin{array}{c}\text { Hypothyroid patients on } \\
\text { thyroxine replacement }\end{array}$ & $\begin{array}{c}\text { No consistent change } \\
\left(\mathrm{T}_{4} \uparrow \text { at } 1 \text { and } 14 \text { days } \mathrm{TSH} \downarrow \text { the first day) }\right.\end{array}$ & {$[32]$} \\
\hline
\end{tabular}

mitochondrial ROS generation is primarily due to electrons leaking from the electron transport chain (ETC) to generate superoxide radical. Superoxide from the electron transport chain and other sources is converted by MnSOD to $\mathrm{H}_{2} \mathrm{O}_{2}$, which is then metabolized by $\operatorname{Prx} 3$ to water [47].

Besides, we demonstrated that high concentrated iodide induces significant increased expression of $\operatorname{Prx} 3$, which suggests that the increase of $\operatorname{Prx} 3$ expression following high concentrated iodide exposure or HI diet in the thyroid may be the protective response against high ROS generation. $\operatorname{Prx} 3$ is an indispensable ROS scavenger that protects against oxidative damage and subsequent apoptosis [51-53]. It is reported that Prx 3 has an essential role in regulating oxidationinduced apoptosis and can be a potential therapeutic target in castrate-independent prostate cancer [52]. Iodide had a stimulatory effect on $\mathrm{H}_{2} \mathrm{O}_{2}$ generation in thyroid slices [1]. At high concentrations (above $0.1 \mathrm{mM}$ ), $\mathrm{H}_{2} \mathrm{O}_{2}$ induces apoptosis in thyroid cells [1]. When iodide is in excess as compared to tyrosine residues, it reacts with the iodonium cation formed by iodide oxidation to give molecular iodine. Excess molecular iodine then induced apoptosis through generation of free radicals [54]. $\mathrm{H}_{2} \mathrm{O}_{2}$ generation is a limiting step in thyroid hormone biosynthesis; it is essential for iodide oxidation by thyroperoxidase $[14,55,56] . \mathrm{H}_{2} \mathrm{O}_{2}$ can be eliminated by Prx 3. In mammals, Prx 3 is targeted to the mitochondrial matrix. It is estimated that Prx 3 will be the target for up to $90 \%$ of hydrogen peroxide generated in the mitochondrial matrix [57]; mitochondrial peroxiredoxins (3 and/or 5) can reduce $\mathrm{H}_{2} \mathrm{O}_{2}$ to water through reducing equivalents provided by thiol-containing proteins [58, 59], but the mechanisms involved are unclear [24, 59]. Drechsel and Patel demonstrated that thioredoxin (Trxs)/peroxiredoxin (Prxs) (Prx 3 and Prx 5) is the major contributing system to $\mathrm{H}_{2} \mathrm{O}_{2}$ removal in brain mitochondria [60]. Prxs and Trxs are important liver antioxidant proteins and play important roles in maintaining liver redox homeostasis [61]. It is reported that chronic ethanol exposure increases NADPH oxidase activity and increases the production of superoxide and hydrogen peroxide [62-64]. Thioredoxin scavenges and reduces ROS via peroxiredoxins [65]. Endoplasmic reticulum stress disrupts the electron transport chain, leading to the increased production of $\operatorname{ROS}[48,49]$. Bae et al. reported that the antioxidant role of $\operatorname{Prx} 3$ was evident from the findings that pyrazole-induced protein carbonylation and the formation of 4-HNE adducts and MDA in the liver were markedly increased in Prx $3^{-/-}$mice compared with wildtype mice [66].

A high urinary excretion of iodine in a spot urine sample is the ultimate proof of iodine excess in vivo [2]. We showed the urinary iodine concentration increased as the iodide supply increased; significantly higher urinary iodine concentration can be detected in $100 \mathrm{HI}$ than $10 \mathrm{HI}$ and in MT-I/II $\mathrm{KO}$ mice than in WT mice. This data indicates the adaptation of the thyroid gland to iodine excess and that the excessive iodine is excreted from the urine in order to maintain the normal function of thyroid. This makes the studies in vivo different from studies in vitro. In addition to the urinary excretion of iodine, there are many control mechanisms of the thyroid to counteract iodide excess. These include the sodium-iodide symporter, which controls the limiting step of thyroid hormone synthesis, the Wolff-Chaikoff effect, an arrest of thyroid hormone secretion from stores in the colloid, a preferential secretion of the less active $T_{4}$ over $T_{3}$, and dumping of excess iodine by secreting it in nonhormonal form [2].

Moreover, we demonstrated that significant increases of mitochondrial superoxide production and Prx 3 protein expression can be detected in MT-I/II KO mice group. This data indicated the protective role of MT-I/II against high concentrations of iodide induced mitochondrial superoxide production in the thyrocytes. MT has been demonstrated to play a key role in the detoxification of heavy metals, protecting against various forms of oxidative injury by scavenging oxygen free radicals. MTs belong to the group of intracellular cysteine-rich, metal-binding proteins which is widely expressed in cells (nuclei and/or cytoplasm) of various 
organs and tumors [67-69]. MTs play a protective role in preventing against intoxication with heavy metals, such as $\mathrm{Pb}, \mathrm{Hg}, \mathrm{Cu}$, and $\mathrm{Cd}[67,70]$. All 20 cysteine sulfur atoms are involved in the radical quenching process, and the rate constant for the reaction of hydroxyl radical with MT is about 340-fold higher than that with GSH [71, 72]. There are four MT isoforms in mammals. MT-I and MT-II are mainly involved in the protection of tissue against metal toxicities, oxidative stresses, and apoptosis. It has been demonstrated that the rabbit liver metallothionein-1, which contains zinc and/or cadmium ions, appeared to scavenge free hydroxyl and superoxide radicals $[25,26]$. Under low levels of iodide organification in goitrous-modified tissue of thyroid gland, metallothionein may provide a partial compensatory effect on prooxidative processes $[73,74]$. Although no cell line or animal model overexpressing MT in the thyroid has been found yet, documented evidence of MT in protecting against oxidative stress in cardiac-specific metallothioneinoverexpressed transgenic mice has been demonstrated. Cai et al. reported that metallothionein, as a potent antioxidant, prevented the development of diabetic cardiomyopathy through the inhibition of the mitochondrial cytochrome c-mediated caspase-3 activation pathway [75]. Sun et al. reported that, through doxorubicin induced chronic toxicity in a metallothionein-overexpressed transgenic mouse heart, the antioxidant action of MT is highly responsible for this cardioprotection [76]. Ceylan-Isik et al. reported that the cardiac-specific overexpression of MT rescues LPSinduced cardiac contractile and intracellular $\mathrm{Ca}^{2+}$ dysfunctions through the alleviation of ROS/oxidative stress, stress signaling activation, and endoplasmic reticulum (ER) stress [77]. They also reported that the cardiac-specific overexpression of metallothionein protects against nicotine exposureinduced cardiac contractile dysfunction and fibrosis possibly through inhibition of ROS accumulation and apoptosis [78]. Zhang et al. suggest that cardiac overexpression of metallothionein prevents cold exposure-induced cardiac anomalies, possibly through the attenuation of myocardial fibrosis [79]. $\mathrm{Hu}$ et al. demonstrated that cardiac-specific overexpression of metallothionein protects against cigarette smoking exposureinduced myocardial contractile and mitochondrial damage, favoring a role of lessened apoptosis in a metallothioneininduced beneficial effect against side-stream smoke exposure [80]. Besides, metallothionein has been shown to regulate apoptosis and proliferation. Overexpression of metallothionein frequently occurs in human tumors and is related to tumor progression $[81,82]$. High expression of MT has been observed in different types of cancer and has been considered as a potential prognostic marker in cancers of the breast, pancreas, skin, and cervix [82-86]. Further studies will be attempted to study the oxidative and antioxidative stress on an engineered cell line overexpressing metallothionein.

\section{Conclusion}

The present study provides evidence that high concentrations of iodide may lead to a significant increase in mitochondrial superoxide production and $\operatorname{Prx} 3$ expression in both in vitro and in vivo studies. MT-I/II KO mice aggravated mitochondrial superoxide production and peroxiredoxin 3 expression in the thyroid after excessive iodide exposure. MT-I/II may potentially protect the thyroid against high concentrations of iodide induced oxidative stress.

$\begin{array}{ll}\text { Abbreviations } \\ \text { MT-I/II KO: } \\ \text { MTs: } & \text { Metallothionein I/II knockout } \\ \text { WT: } & \text { Wild-type } \\ \text { ROS: } & \text { Reactive oxygen species } \\ \text { Prx: } & \text { Peroxiredoxin } \\ \text { KI: } & \text { Potassium iodide } \\ \mathrm{NI}: & \text { Normal iodide intake } \\ \mathrm{HI}: & \text { High iodide intake } \\ \mathrm{LDH}: & \text { Lactate dehydrogenase } \\ \mathrm{H}_{2} \mathrm{O}_{2}: & \text { Hydrogen peroxide } \\ \mathrm{SOD}: & \text { Superoxide dismutase } \\ \mathrm{MTT}: & \text { 3-(4,5-Dimethylthiazol-2-yl)-2,5- } \\ & \text { diphenyltetrazolium } \\ & \text { bromide } \\ \mathrm{K}_{\mathrm{S}}: & \text { Kolmogorov-Smirnov } \\ \mathrm{LSD}_{\mathrm{S}}: & \text { Least significant difference } \\ \mathrm{T}_{4}: & \text { Thyroxine } \\ \mathrm{T}_{3}: & \text { Tri-iodothyronine } \\ \mathrm{FT}_{4}: & \text { Free thyroxine } \\ \mathrm{FT}_{3}: & \text { Free tri-iodothyronine. }\end{array}$

\section{Conflict of Interests}

The authors declare that they have no competing interests.

\section{Acknowledgments}

This work is supported by the National Natural Science Foundation of China (no. 81273009), the Tianjin Science \& Technology Council Grant of China (no. 09JCYBJC11700), and the Tianjin Educational \& Scientific Grant (no. 20050107). This paper has been edited by one of the authors, Mohamed Ahmed, who is from USA and now is studying in Tianjin Medical University, China.

\section{References}

[1] B. Corvilain, L. Collyn, J. van Sande, and J. E. Dumont, "Stimulation by iodide of $\mathrm{H}_{2} \mathrm{O}_{2}$ generation in thyroid slices from several species," The American Journal of PhysiologyEndocrinology and Metabolism, vol. 278, no. 4, pp. E692-E699, 2000.

[2] H. Bürgi, "Iodine excess," Best Practice \& Research: Clinical Endocrinology \& Metabolism, vol. 24, no. 1, pp. 107-115, 2010.

[3] E. Roti and E. Degli Uberti, "Iodine excess and hyperthyroidism," Thyroid, vol. 11, no. 5, pp. 493-500, 2001.

[4] World Health Organization and United Nations Children's Fund, "International Council for Control of Iodine Deficiency Disorders 1999 progress towards the elimination of iodine deficiency disorders (IDD)," WHO Booklet, World Health Organization, 1999. 
[5] A. M. Leung and L. E. Braverman, "Consequences of excess iodine," Nature Reviews Endocrinology, vol. 10, no. 3, pp. 136142, 2013.

[6] M. B. Zimmermann, P. L. Jooste, and C. S. Pandav, "Iodinedeficiency disorders," The Lancet, vol. 372, no. 9645, pp. 12511262, 2008.

[7] I. Mahmoud, I. Colin, M. C. Many, and J.-F. Denef, "Direct toxic effect of iodide in excess on iodine-deficient thyroid glands: epithelial necrosis and inflammation associated with lipofuscin accumulation," Experimental and Molecular Pathology, vol. 44, no. 3, pp. 259-271, 1986.

[8] J. E. Fradkin and J. Wolff, "Iodide-induced thyrotoxicosis," Medicine, vol. 62, no. 1, pp. 1-20, 1983.

[9] J. Golstein and J. E. Dumont, "Cytotoxic effects of iodide on thyroid cells: difference between rat thyroid FRTL-5 cell and primary dog thyrocyte responsiveness," Journal of Endocrinological Investigation, vol. 19, no. 2, pp. 119-126, 1996.

[10] M.-C. Many, C. Mestdagh, M.-F. van den Hove, and J.-F. Denef, "In vitro study of acute toxic effects of high iodide doses in human thyroid follicles," Endocrinology, vol. 131, no. 2, pp. 621630, 1992.

[11] W. Teng, Z. Shan, X. Teng et al., "Effect of iodine intake on thyroid diseases in China," The New England Journal of Medicine, vol. 354, no. 26, pp. 2783-2793, 2006.

[12] P. Laurberg, K. M. Pedersen, A. Hreidarsson, N. Sigfusson, E. Iversen, and P. R. Knudsen, "Iodine intake and the pattern of thyroid disorders: a comparative epidemiological study of thyroid abnormalities in the elderly in iceland and in Jutland, Denmark," Journal of Clinical Endocrinology and Metabolism, vol. 83, no. 3, pp. 765-769, 1998.

[13] P. Laurberg, C. Cerqueira, L. Ovesen et al., "Iodine intake as a determinant of thyroid disorders in populations," Best Practice and Research: Clinical Endocrinology and Metabolism, vol. 24, no. 1, pp. 13-27, 2010.

[14] S. Poncin, A.-C. Gérard, M. Boucquey et al., "Oxidative stress in the thyroid gland: from harmlessness to hazard depending on the iodine content," Endocrinology, vol. 149, no. 1, pp. 424-433, 2008.

[15] X. Yao, M. Li, J. He et al., "Effect of early acute high concentrations of iodide exposure on mitochondrial superoxide production in FRTL cells," Free Radical Biology and Medicine, vol. 52, no. 8, pp. 1343-1352, 2012.

[16] H. Han, P. Xin, L. Zhao et al., "Excess iodine and high-fat diet combination modulates lipid profile, thyroid hormone, and hepatic LDLr expression values in mice," Biological Trace Element Research, vol. 147, no. 1-3, pp. 233-239, 2012.

[17] S.-J. Zhao, Y. Ye, F.-J. Sun, E.-J. Tian, and Z.-P. Chen, "The impact of dietary iodine intake on lipid metabolism in mice," Biological Trace Element Research, vol. 142, no. 3, pp. 581-588, 2011.

[18] X. Teng, Z. Shan, W. Teng, C. Fan, H. Wang, and R. Guo, "Experimental study on the effects of chronic iodine excess on thyroid function, structure, and autoimmunity in autoimmuneprone NOD.H-2h4 mice," Clinical and Experimental Medicine, vol. 9, no. 1, pp. 51-59, 2009.

[19] V. Pitsiavas, P. Smerdely, M. Li, and S. C. Boyages, "Amiodarone induces a different pattern of ultrastructural change in the thyroid to iodine excess alone in both the $\mathrm{BB} / \mathrm{W}$ rat and the Wistar rat," European Journal of Endocrinology, vol. 137, no. 1, pp. 89-98, 1997.
[20] M. B. Zimmermann, "Iodine deficiency and excess in children: worldwide status in 2013," Endocrine Practice, vol. 19, no. 5, pp. 839-846, 2013.

[21] K. Müssig, "Iodine-induced toxic effects due to seaweed consumption," in Comprehensive Handbook of Iodine, V. R. Preedy, G. N. Burrow, and R. R. Watson, Eds., pp. 897-908, Elsevier, Amsterdam, The Netherlands, 2009.

[22] A.-M. G. Psarra, S. Solakidi, and C. E. Sekeris, "The mitochondrion as a primary site of action of steroid and thyroid hormones: presence and action of steroid and thyroid hormone receptors in mitochondria of animal cells," Molecular and Cellular Endocrinology, vol. 246, no. 1-2, pp. 21-33, 2006.

[23] Y. Song, N. Driessens, M. Costa et al., "Roles of hydrogen peroxide in thyroid physiology and disease," Journal of Clinical Endocrinology and Metabolism, vol. 92, no. 10, pp. 3764-3773, 2007.

[24] A. G. Cox, C. C. Winterbourn, and M. B. Hampton, "Mitochondrial peroxiredoxin involvement in antioxidant defence and redox signalling," Biochemical Journal, vol. 425, no. 2, pp. 313-325, 2010.

[25] B. Ruttkay-Nedecky, L. Nejdl, J. Gumulec et al., "The role of metallothionein in oxidative stress," International Journal of Molecular Sciences, vol. 14, no. 3, pp. 6044-6066, 2013.

[26] N. Thirumoorthy, A. Shyam Sunder, K. T. Manisenthil Kumar, M. Senthil kumar, G. N. K. Ganesh, and M. Chatterjee, "A review of metallothionein isoforms and their role in pathophysiology," World Journal of Surgical Oncology, vol. 9, article 54, 2011.

[27] T. Paul, B. Meyers, R. J. Witorsch et al., "The effect of small increases in dietary iodine on thyroid function in euthyroid subjects," Metabolism, vol. 37, no. 2, pp. 121-124, 1988.

[28] M. Saberi and R. D. Utiger, "Augmentation of thyrotropin responses to thyrotropin releasing hormone following small decreases in serum thyroid hormone concentrations," The Journal of Clinical Endocrinology and Metabolism, vol. 40, no. 3, pp. 435-441, 1975.

[29] H. Namba, S. Yamashita, H. Kimura et al., "Evidence of thyroid volume increase in normal subjects receiving excess iodide," The Journal of Clinical Endocrinology and Metabolism, vol. 76, no. 3, pp. 605-608, 1993.

[30] E. Sternthal, L. Lipworth, B. Stanley, C. Abreau, S. L. Fang, and L. E. Braverman, "Suppression of thyroid radioiodine uptake by various doses of stable iodide," The New England Journal of Medicine, vol. 303, no. 19, pp. 1083-1088, 1980.

[31] A. G. Vagenakis, B. Rapoport, F. Azizi, G. I. Portnay, L. E. Braverman, and S. H. Ingbar, "Hyperresponse to thyrotropin releasing hormone accompanying small decreases in serum thyroid hormone concentrations," The Journal of Clinical Investigation, vol. 54, no. 4, pp. 913-918, 1974.

[32] G. Philippou, D. A. Koutras, G. Piperingos, A. Souvatzoglou, and S. D. Moulopoulos, "The effect of iodide on serum thyroid hormone levels in normal persons, in hyperthyroid patients, and in hypothyroid patients on thyroxine replacement," Clinical Endocrinology, vol. 36, no. 6, pp. 573-578, 1992.

[33] L. Z. Ali Salim, R. Othman, M. A. Abdulla et al., "Thymoquinone inhibits murine leukemia WEHI-3 cells in vivo and in vitro," PLoS ONE, vol. 9, no. 12, Article ID el15340, 2014.

[34] X. Wang, J. Ge, K. Wang, J. Qian, and Y. Zou, "Evaluation of MTT assay for measurement of emodin-induced cytotoxicity," ASSAY and Drug Development Technologies, vol. 4, no. 2, pp. 203-207, 2006. 
[35] C. Lv, C. Wu, Y.-h. Zhou, Y. Shao, G. Wang, and Q.-y. Wang, "Alpha lipoic acid Modulated high glucose-induced rat mesangial cell dysfunction via mTOR/p70S6K/4E-BP1 pathway," International Journal of Endocrinology, vol. 2014, Article ID 658589, 14 pages, 2014.

[36] L. Liu, X. Hu, G.-Y. Cai et al., "High glucose-induced hypertrophy of mesangial cells is reversed by connexin 43 overexpression via PTEN/Akt/mTOR signaling," Nephrology Dialysis Transplantation, vol. 27, no. 1, pp. 90-100, 2012.

[37] D. D. Harrison-Findik, S. Z. Lu, E. M. Zmijewski, J. Jones, and M. C. Zimmerman, "Effect of alcohol exposure on hepatic superoxide generation and hepcidin expression," World Journal of Biological Chemistry, vol. 4, no. 4, pp. 119-130, 2013.

[38] M. Wang, Y. Wang, J. He et al., "Albumin induces neuroprotection against ischemic stroke by altering Toll-like receptor 4 and regulatory T cells in mice," CNS and Neurological DisordersDrug Targets, vol. 12, no. 2, pp. 220-227, 2013.

[39] X. Yao, "Effect of zinc exposure on HNE and GLT-1 in spinal cord culture," NeuroToxicology, vol. 30, no. 1, pp. 121-126, 2009.

[40] P. L. Jooste and E. Strydom, "Methods for determination of iodine in urine and salt," Best Practice and Research: Clinical Endocrinology and Metabolism, vol. 24, no. 1, pp. 77-88, 2010.

[41] G. P. Becks, M. C. Eggo, and G. N. Burrow, "Regulation of differentiated thyroid function by iodide: preferential inhibitory effect of excess iodide on thyroid hormone secretion in sheep thyroid cell cultures," Endocrinology, vol. 120, no. 6, pp. 25692575, 1987.

[42] M. Vitale, T. Di Matola, F. D’Ascoli et al., "Iodide excess induces apoptosis in thyroid cells through a p53-independent mechanism involving oxidative stress," Endocrinology, vol. 141, no. 2, pp. 598-605, 2000.

[43] P. Pramyothin, A. M. Leung, E. N. Pearce, A. O. Malabanan, and L. E. Braverman, "Clinical problem-solving. A hidden solution," The New England Journal of Medicine, vol. 365, no. 22, pp. 21232127, 2011.

[44] W. Jubiz, S. Carlile, and L. D. Lagerquist, "Serum thyrotropin and thyroid hormone levels in humans receiving chronic potassium iodide," The Journal of Clinical Endocrinology and Metabolism, vol. 44, no. 2, pp. 379-382, 1977.

[45] A. G. Vagenakis, P. Downs, L. E. Braverman, A. Burger, and S. H. Ingbar, "Control of thyroid hormone secretion in normal subjects receiving iodides.", The Journal of Clinical Investigation, vol. 52, no. 2, pp. 528-532, 1973.

[46] M. Safran and L. E. Braverman, "Effect of chronic douching with polyvinylpyrrolidone-iodine on iodine absorption and thyroid function," Obstetrics and Gynecology, vol. 60, no. 1, pp. 35-40, 1982.

[47] K. Newick, B. Cunniff, K. Preston et al., "Peroxiredoxin 3 is a redox-dependent target of thiostrepton in malignant mesothelioma cells," PLoS ONE, vol. 7, no. 6, Article ID e39404, 2012.

[48] A. Deniaud, O. S. El Dein, E. Maillier et al., "Endoplasmic reticulum stress induces calcium-dependent permeability transition, mitochondrial outer membrane permeabilization and apoptosis," Oncogene, vol. 27, no. 3, pp. 285-299, 2008.

[49] A. Görlach, P. Klappa, and T. Kietzmann, “The endoplasmic reticulum: folding, calcium homeostasis, signaling, and redox control," Antioxidants and Redox Signaling, vol. 8, no. 9-10, pp. 1391-1418, 2006.

[50] C. Serrano-Nascimento, S. D. S. Teixeira, J. P. Nicola, R. T. Nachbar, A. M. Masini-Repiso, and M. T. Nunes, "The acute inhibitory effect of iodide excess on sodium/iodide symporter expression and activity involves the PI3K/Akt signaling pathway," Endocrinology, vol. 155, no. 3, pp. 1145-1156, 2014.

[51] Y.-G. Wang, L. Li, C.-H. Liu, S. Hong, and M.-J. Zhang, "Peroxiredoxin 3 is resistant to oxidation-induced apoptosis of Hep-3b cells," Clinical and Translational Oncology, vol. 16, no. 6, pp. 561-566, 2014.

[52] H. C. Whitaker, D. Patel, W. J. Howat et al., "Peroxiredoxin-3 is overexpressed in prostate cancer and promotes cancer cell survival by protecting cells from oxidative stress," British Journal of Cancer, vol. 109, no. 4, pp. 983-993, 2013.

[53] L. Li, Y. G. Zhang, and C. L. Chen, "Anti-apoptotic role of peroxiredoxin III in cervical cancer cells," FEBS Open Bio, vol. 3, pp. 51-54, 2013.

[54] A. E. Joanta, A. Filip, S. Clichici, S. Andrei, and D. Daicoviciu, "Iodide excess exerts oxidative stress in some target tissues of the thyroid hormones," Acta Physiologica Hungarica, vol. 93, no. 4, pp. 347-359, 2006.

[55] L. I. Nadolnik, Z. V. Niatsetskaya, and S. V. Lupachyk, "Effect of oxidative stress on rat thyrocyte iodide metabolism," Cell Biochemistry and Function, vol. 26, no. 3, pp. 366-373, 2008.

[56] A. C. Freitas Ferreira, L. de Carvalho Cardoso, D. Rosenthal, and D. Pires de Carvalho, "Thyroid $\mathrm{Ca}^{2+} / \mathrm{NADPH}$-dependent $\mathrm{H}_{2} \mathrm{O}_{2}$ generation is partially inhibited by propylthiouracil and methimazole," European Journal of Biochemistry, vol. 270, no. 11, pp. 2363-2368, 2003.

[57] G. R. Sue, Z. C. Ho, and K. Kim, "Peroxiredoxins: a historical overview and speculative preview of novel mechanisms and emerging concepts in cell signaling," Free Radical Biology and Medicine, vol. 38, no. 12, pp. 1543-1552, 2005.

[58] M. S. Seo, S. W. Kang, K. Kim, I. C. Baines, T. H. Lee, and S. G. Rhee, "Identification of a new type of mammalian peroxiredoxin that forms an intramolecular disulfide as a reaction intermediate," Journal of Biological Chemistry, vol. 275, no. 27, pp. 20346-20354, 2000.

[59] Z. A. Wood, L. B. Poole, and P. A. Karplus, "Peroxiredoxin evolution and the regulation of hydrogen peroxide signaling," Science, vol. 300, no. 5619, pp. 650-653, 2003.

[60] D. A. Drechsel and M. Patel, "Respiration-dependent $\mathrm{H}_{2} \mathrm{O}_{2}$ removal in brain mitochondria via the thioredoxin/peroxiredoxin system," The Journal of Biological Chemistry, vol. 285, no. 36, pp. 27850-27858, 2010.

[61] W. H. Watson, X. Yang, Y. E. Choi, D. P. Jones, and J. P. Kehrer, "Thioredoxin and its role in toxicology," Toxicological Sciences, vol. 78, no. 1, pp. 3-14, 2004.

[62] G. Ekstrom and M. Ingelman-Sundberg, "Rat liver microsomal NADPH-supported oxidase activity and lipid peroxidation dependent on ethanol-inducible cytochrome P-450 (P450IIE1)," Biochemical Pharmacology, vol. 38, no. 8, pp. 13131319, 1989.

[63] J. Rashba-Step, N. J. Turro, and A. I. Cederbaum, "Increased $\mathrm{NADPH}$ - and NADH-dependent production of superoxide and hydroxyl radical by microsomes after chronic ethanol treatment," Archives of Biochemistry and Biophysics, vol. 300, no. 1, pp. 401-408, 1993.

[64] V. Thakur, M. T. Pritchard, M. R. McMullen, Q. Wang, and L. E. Nagy, "Chronic ethanol feeding increases activation of NADPH oxidase by lipopolysaccharide in rat Kupffer cells: role of increased reactive oxygen in LPS-stimulated ERK1/2 activation and TNF- $\alpha$ production," Journal of Leukocyte Biology, vol. 79, no. 6, pp. 1348-1356, 2006. 
[65] H. Nakamura, A. Mitsui, and J. Yodoi, "Thioredoxin overexpression in transgenic mice," Methods in Enzymology, vol. 347, pp. 436-440, 2002.

[66] S. H. Bae, S. H. Sung, H. E. Lee et al., "Peroxiredoxin III and sulfiredoxin together protect mice from pyrazole-induced oxidative liver injury," Antioxidants \& Redox Signaling, vol. 17, no. 10, pp. 1351-1361, 2012.

[67] A. Bieniek, B. Pula, A. Piotrowska et al., "Expression of metallothionein I/II and Ki-67 antigen in various histological types of basal cell carcinoma," Folia Histochemica et Cytobiologica, vol. 50, no. 3, pp. 352-357, 2012.

[68] P. Dziegiel, "Expression of metallothioneins in tumor cells," Polish Journal of Pathology, vol. 55, no. 1, pp. 3-12, 2004.

[69] M. Ø. Pedersen, A. Larsen, M. Stoltenberg, and M. Penkowa, "The role of metallothionein in oncogenesis and cancer prognosis," Progress in Histochemistry and Cytochemistry, vol. 44, no. 1, pp. 29-64, 2009.

[70] W. Braun, M. Vašák, A. H. Robbins et al., "Comparison of the NMR solution structure and the X-ray crystal structure of rat metallothionein-2," Proceedings of the National Academy of Sciences of the United States of America, vol. 89, no. 21, pp. 1012410128, 1992.

[71] P. J. Thornalley and M. Vasak, "Possible role for metallothionein in protection against radiation-induced oxidative stress. Kinetics and mechanism of its reaction with superoxide and hydroxyl radicals," Biochimica et Biophysica Acta: Protein Structure and Molecular Enzymology, vol. 827, no. 1, pp. 36-44, 1985.

[72] M. A. Schwarz, J. S. Lazo, J. C. Yalowich et al., "Metallothionein protects against the cytotoxic and DNA-damaging effects of nitric oxide," Proceedings of the National Academy of Sciences of the United States of America, vol. 92, no. 10, pp. 4452-4456, 1995.

[73] Y. Luo, A. Kawashima, and Y. Ishido, "Iodine excess as an environmental risk factor for autoimmune thyroid disease," International Journal of Molecular Sciences, vol. 15, pp. 1289512912, 2014.

[74] H. I. Fal'fushins'ka, L. L. Hnatyshyna, and OĬ. Osadchuk, “Trace elements storage peculiarities and metallothionein content in human thyroid gland under iodine deficiency euthyroid nodular goiter," Ukrainskii Biokhimicheskii Zhurnal, vol. 86, pp. 107-113, 2014.

[75] L. Cai, Y. H. Wang, G. H. Zhou et al., "Attenuation by metallothionein of early cardiac cell death via suppression of mitochondrial oxidative stress results in a prevention of diabetic cardiomyopathy," Journal of the American College of Cardiology, vol. 48, no. 8, pp. 1688-1697, 2006.

[76] X. Sun, Z. Zhou, and Y. J. Kang, "Attenuation of doxorubicin chronic toxicity in metallothionein-overexpressing transgenic mouse heart," Cancer Research, vol. 61, no. 8, pp. 3382-3387, 2001.

[77] A. F. Ceylan-Isik, P. Zhao, B. F. Zhang, X. Xiao, G. Su, and J. Ren, "Cardiac overexpression of metallothionein rescues cardiac contractile dysfunction and endoplasmic reticulum stress but not autophagy in sepsis," Journal of Molecular and Cellular Cardiology, vol. 48, no. 2, pp. 367-378, 2010.

[78] N. Hu, R. Guo, X. Han, B. Zhu, and J. Ren, "Cardiac-specific overexpression of metallothionein rescues nicotine-induced cardiac contractile dysfunction and interstitial fibrosis," Toxicology Letters, vol. 202, no. 1, pp. 8-14, 2011.

[79] Y. Zhang, N. Hu, Y. Hua, K. L. Richmond, F. Dong, and J. Ren, "Cardiac overexpression of metallothionein rescues cold exposure-induced myocardial contractile dysfunction through attenuation of cardiac fibrosis despite cardiomyocyte mechanical anomalies," Free Radical Biology and Medicine, vol. 53, no. 2, pp. 194-207, 2012.

[80] N. Hu, X. Han, E. K. Lane, F. Gao, Y. Zhang, and J. Ren, "Cardiac-specific overexpression of metallothionein rescues against cigarette smoking exposure-induced myocardial contractile and mitochondrial damage," PLoS ONE, vol. 8, no. 2, Article ID e57151, 2013.

[81] M. T. Brazão-Silva, S. V. Cardoso, P. R. de Faria et al., "Adenoid cystic carcinoma of the salivary gland: a clinicopathological study of 49 cases and of metallothionein expression with regard to tumour behaviour," Histopathology, vol. 63, no. 6, pp. 802809, 2013.

[82] K. J. Schmitz, H. Lang, G. Kaiser et al., "Metallothionein overexpression and its prognostic relevance in intrahepatic cholangiocarcinoma and extrahepatic hilar cholangiocarcinoma (Klatskin tumors)," Human Pathology, vol. 40, no. 12, pp. 1706-1714, 2009.

[83] S. E. Theocharis, A. P. Margeli, J. T. Klijanienko, and G. P. Kouraklis, "Metallothionein expression in human neoplasia," Histopathology, vol. 45, no. 2, pp. 103-118, 2004.

[84] S. Theocharis, J. Klijanienko, C. Giaginis et al., "Metallothionein expression in mobile tongue squamous cell carcinoma: associations with clinicopathological parameters and patient survival," Histopathology, vol. 59, no. 3, pp. 514-525, 2011.

[85] S.-K. Tai, O. J.-K. Tan, V. T.-K. Chow et al., "Differential expression of metallothionein 1 and 2 isoforms in breast cancer lines with different invasive potential: identification of a novel non-silent metallothionein-1H mutant variant," The American Journal of Pathology, vol. 163, no. 5, pp. 2009-2019, 2003.

[86] Y. Hishikawa, T. Koji, D. K. Dhar, S. Kinugasa, M. Yamaguchi, and N. Nagasue, "Metallothionein expression correlates with metastatic and proliferative potential in squamous cell carcinoma of the oesophagus," British Journal of Cancer, vol. 81, no. 4, pp. 712-720, 1999. 


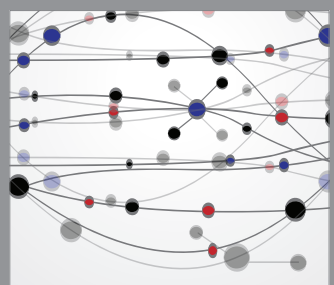

The Scientific World Journal
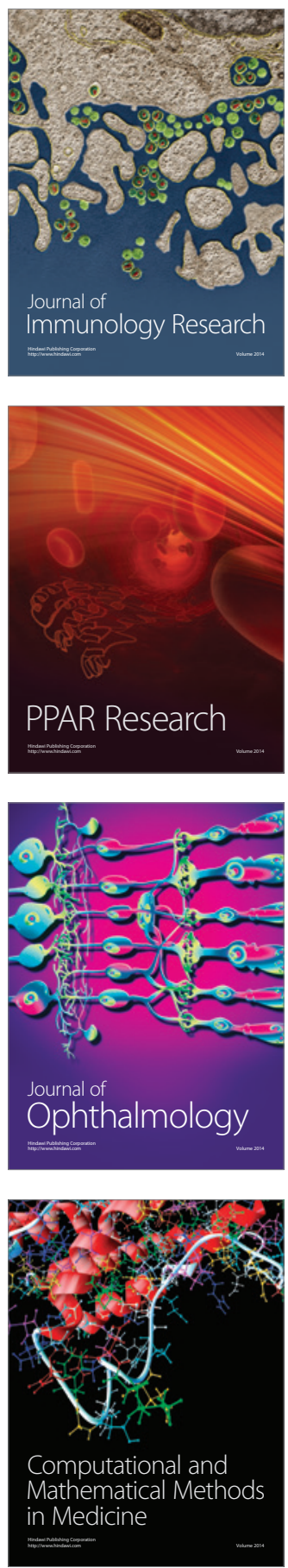

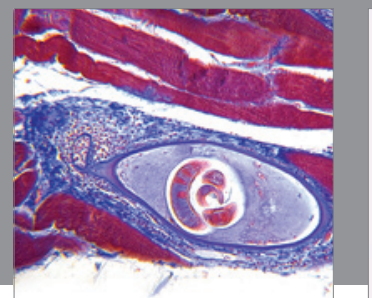

Gastroenterology

Research and Practice
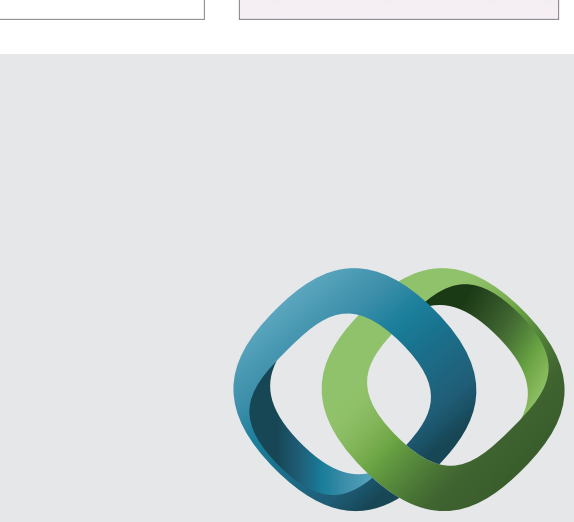

\section{Hindawi}

Submit your manuscripts at

http://www.hindawi.com
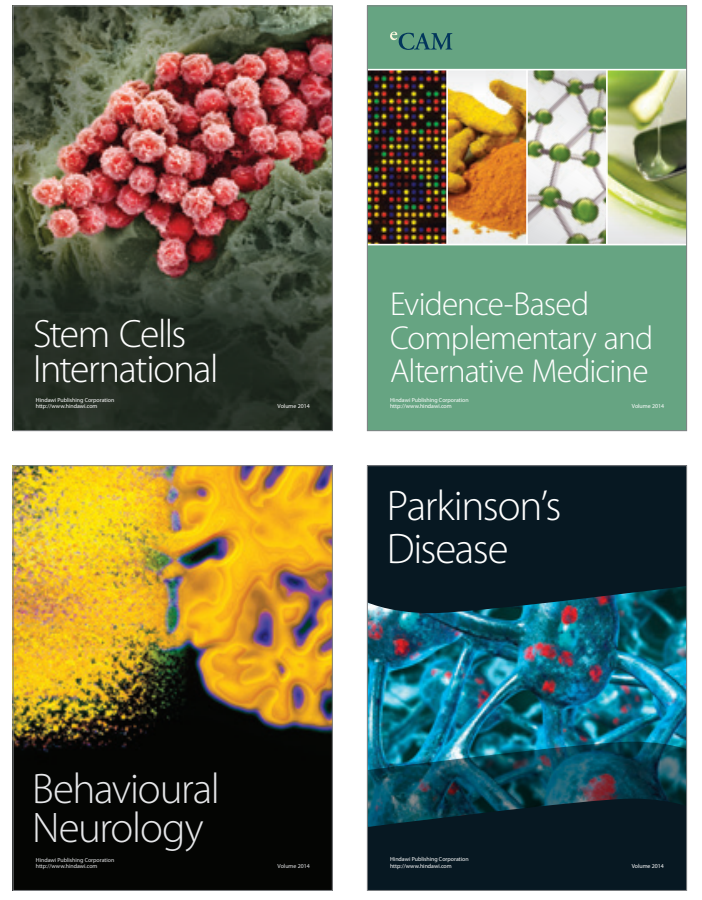
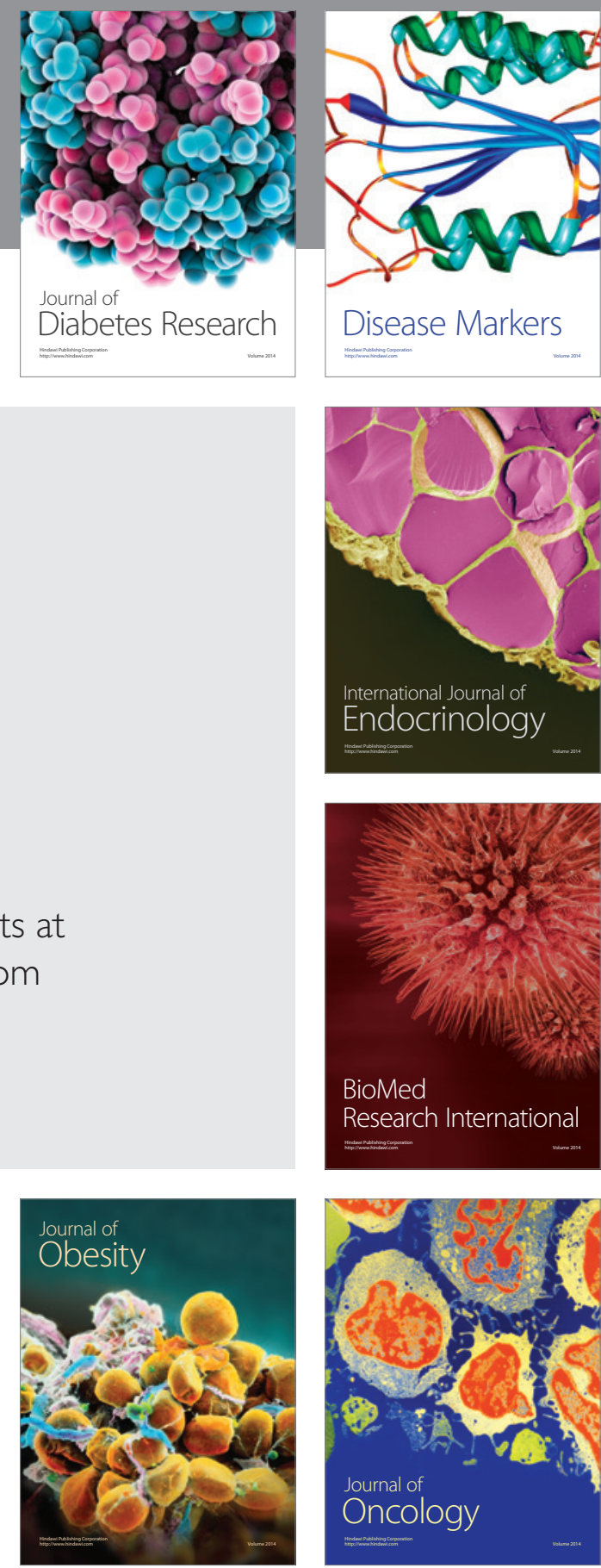

Disease Markers
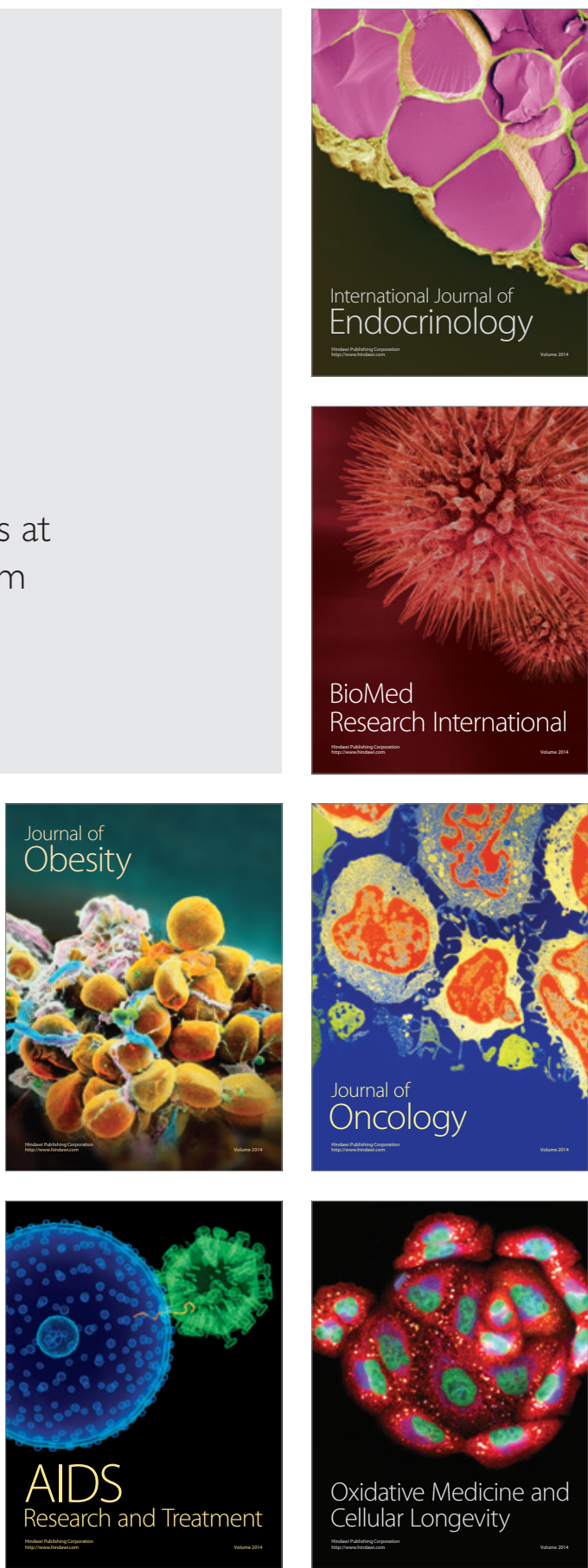